\title{
Income Generation of Non-wood Forest Products in an Innovative Integrated Crop-Livestock-Forestry System
}

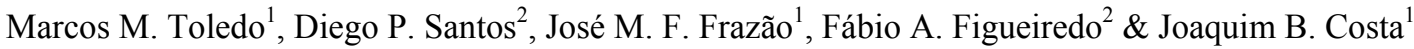 \\ ${ }^{1}$ Brazilian Agricultural Research Corporation, Embrapa Cocais, São Luís, Brazil \\ ${ }^{2}$ State University of Maranhão, São Luís, Brazil \\ Correspondence: Marcos M. Toledo, Brazilian Agricultural Research Corporation, Embrapa Cocais, Av. São Luís \\ Rei de França, Quadra 11, Lote 4, nº 1. Jardim Eldorado, São Luís, Maranhão, Brazil. Tel: 55-98-982-400-081. \\ E-mail: marcos.toledo@embrapa.br
}

Received: June 25, 2020

doi:10.5539/jas.v12n9p235
Accepted: July 31, $2020 \quad$ Online Published: August 15, 2020

URL: https://doi.org/10.5539/jas.v12n9p235

The research is financed by Banco da Amazônia and FAPEMA.

\begin{abstract}
The wide extension area occupied by babassu palm (Atallea speciosa Mart. Ex Spreng) is usually considered as an important obstacle for agricultural activities, such as crop production and pasture maintenance in Brazil. This study aimed to evaluate the non-wood forest product use and income generated in an Integrated Crop-Livestock-Forestry (ICLF) system using babassu palm as the main forestry component in a rural area of Pindaré-Mirim, a municipality of Maranhão state, in the Amazon Eastern Region, Brazil. In order to rise a well-balanced agroforestry system in numerous rural areas of the country, three main questions were addressed in this study: 1) What is the production of babassu fruits in the system? 2) Is the babassu extractivism income economically suitable for traditional communities of women babassu breakers? 3) Which commercialization scenario of NWFP could generate more income? Data on phenology and fruit production, processing of all fruit components, and commercialization of babassu products were collected in two 12-month seasons of palm production (2017/2018 and 2018/2019). The mean fruit production reached 2,345.49 $\mathrm{kg} \mathrm{ha}^{-1}$ season $^{-1}$, resulting in an estimate of income generation ranging from $\mathrm{R} \$ 8,206.96 \mathrm{ha}^{-1}$ season $^{-1}$ to $\mathrm{R} \$ 36,628.54 \mathrm{ha}^{-1}$ season $^{-1}$, depending on the commercialization scenario. These numbers were compared to the statewide monthly income per household of R $\$ 605.00$ and to the per capita monthly income of $54 \%$ of the municipality of less than $\mathrm{R} \$ 499.00$. The real field data and the estimates for two seasons of using babassu palm, as the innovative forestry component in ICLF system, demonstrated that babassu NWFP could generate substantial income for the surrounding user communities. Such innovative agricultural system may contribute to change people understanding, diversifying agrarian production, improving the socioeconomic household welfare, and reducing the long-term conflicts between livestock activities and babassu palm existence in Brazil.
\end{abstract}

Keywords: agrobiodiversity, agroforestry system, traditional communities, Atallea speciosa, babassu use management, social impact

\section{Introduction}

Agroforestry systems could present different levels of complexity and, consequently, diversification of income sources, environmental improvement, and social benefits (Alves, Madari, \& Boddey, 2017). Silvopastoral and agrosilvopastoral systems, with the forest component providing wood products or environmental services, have been abundantly reported (Eichhorn et al., 2006). However, some studies of agrosilvopastoral systems that uses native species providing non-wood forest products (NWFP) are reported in Europe (Calama et al., 2010), Middle East (Valipour et al., 2014) and Africa (Elmqvist, Olsson, Elamin, \& Warren, 2005; Sonwa et al., 2002), but rare studies are reported for neotropical environments (Lima, Scariot, \& Giroldo, 2017).

A silvopastoral system with NWFP extraction has been historically used in a large geographic area of Brazil. Large areas of livestock pasture with native babassu palm tree (Atallea speciosa Mart. Ex Spreng) stands of various densities are very common in the transition area of Amazon, Cerrado and Caatinga biomes (May, Anderson, Frazão, \& Balick, 1985). In these agricultural areas, the babassu fruits are picked by women from the 
surrounding traditional communities (normally non-landholders small farmers). Women have a long-term history breaking the babassu fruits for different purposes and are the so-called "quebradeiras de coco babaçu" (babassu fruit breakers). Among the different processing forms and, then, types of products (Figure 1), seeds are used for extraction of the oil for food or industrial uses, and the shell charcoal for domestic use (R. Porro \& N. S. M. Porro, 2015).

However, the massive presence of babassu palm trees is not desirable by ranchers (Peters, 1992) because some biological characteristics of the species. The fruit has a very high physical resistance and the seed has a remote-tubular germination which enable this plant to dominate most anthropized areas (Henderson, 2006). Moreover, the physical resistance enables the fruits to last viable for long periods on soil surface underneath the trees. The remote-tubular germination process allows a development of a tubular cotyledon that penetrates the soil and starts the initial plant growth, developing the apical meristem in the subsurface (Jackson, 1974). Then, the young plant becomes very resistant to external interactions and aggressions such as fire, pruning, mowing, herbivory predation, etc.; the plant can grow new leaves even after successive events of complete removal of its aerial part (Pinheiro, 1986; May, 1990; Souza, Moraes, \& Gehring, 2016). As a result, babassu benefits from man-made environmental conditions, such as opening forests for pasture or shifting cultivation using fire (Porro, 2005).

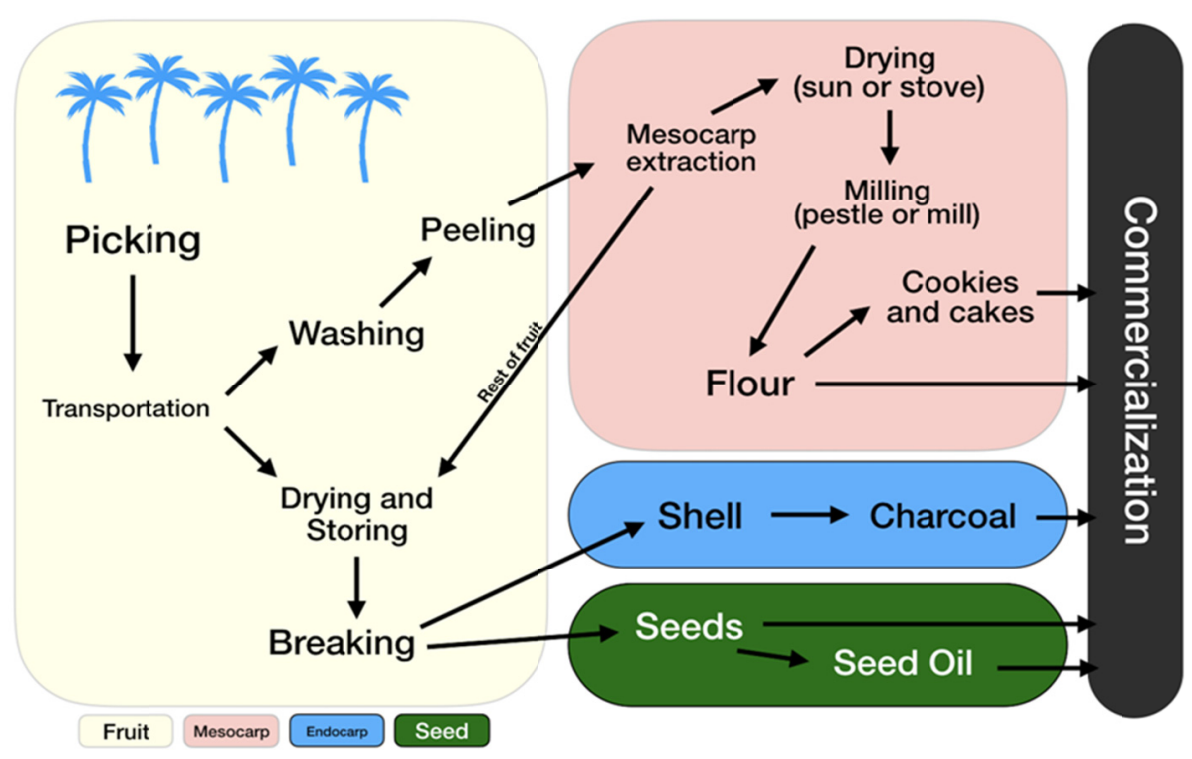

Figure 1. Schematic of main steps of extractivism and processing of babassu fruits (Atallea speciosa Mart. Ex Spreng) and commercialization of the resulting products

Therefore, ranchers consider young babassu plants, popularly called "pindovas", as plague and use manual cutting (brushing) or chemical removal (herbicide) to control massive proliferation once or twice a year. This pasture management requires large investments in labour (May et al., 1985; Porro, 2005). Furthermore, since the 1970s, the access to palm trees for fruit collection is a source of agrarian conflict between babassu extractive communities and the ranchers who own the land (Porro, 2005; R. Porro \& N. S. M. Porro, 2015). Some recent studies on environmental services, soil, pasture quality and production, and animal performance have been conducted in this type of silvopastoral system (Rodrigues et al., 2015, 2016; Araújo et al., 2016; Araújo et al., 2018; Sousa et al., 2016). However, few studies have evaluated the production and use of NWFP of babassu in these traditional systems (Lemos \& Souza, 2018).

The Integrated Crop-Livestock-Forestry (ICLF) system was assembled in Brazil as another agroforestry option for tropical areas (Balbino, Barcelos, \& Stone, 2011). The adoption of ICLF system is expanding throughout the Brazil and is showing good sustainability outcomes (Costa, Schoeneboom, Oliveira, Viñas, \& Medeiros, 2018; Magalhães, Pedreira, Tonini, \& Farias Neto et al., 2019; Reis et al., 2018; Skorupa \& Manzatto, 2019).

Our study innovated the ICLF system for using the widespread species babassu as the forest component. The aim was to reach an agroforestry system that conciliates the ancient low technology silvopastoral system with a more technically managed ICLF system. The use of babassu, a native species, as a source of NWFP, is an innovation 
among the ICLF systems that could have a potential contribution for social and environmental long-term sustainability. Adoption of an innovative integrated agroforestry system could substantially contribute for conserving the on-farm biodiversity and generating ecosystems services (Pinheiro \& Nair, 2018).

In order to reach the previous aim, the present study evaluates this innovative system to address the following questions: 1) What is the production of babassu fruits in the innovative ICLF system with babassu as forestry component? 2) The income of babassu use management in the innovative ICLF system is economically suitable for traditional babassu breakers communities? 3) Which commercial scenario of NWFP from babassu could generate more income for babassu breakers communities? Our main hypothesis is that the innovative ICLF system in test could provide substantial income by managing, processing, and using more efficiently all parts of babassu fruits for their commercialization.

\section{Method}

This study was carried out at a farm ranch called Fazenda Muniz in the municipality of Pindaré-Mirim,

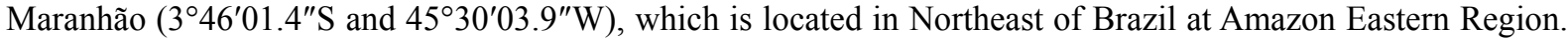
The climate of the region is classified according to Köppen (1948), as Aw (hot and humid), with average annual temperature of $26{ }^{\circ} \mathrm{C}$, annual rainfall between 2,000 and 2,400 $\mathrm{mm}$ and relative annual air humidity between 79\% and 82\% (Secretaria de Estado do Planejamento e Orçamento [SEPLAN], 2013; Alvares, Stape, Sentelhas, Gonçalves, \& Sparrovek, 2014). The soil of the study area is classified as Hapless Plinthsol, originally covered by tropical forest vegetation, sub-perennial, and dactyl-palmaceous-babassual.

An area of 6.0 hectares with native babassu naturally dispersed was used to install an experiment of Integrated Crop-Livestock-Forestry (ICLF) system. Babassu was considered the forestry component of the innovative ICLF system. Initially, a consortium of corn (Zea mays L.) and massai grass (Megathyrsus maximum cv. Massai) was planted, as row crops, with $0.9 \mathrm{~m}$ between rows. After the harvest of corn, the grass was left to grow for pasture. Among all the 212 babassu palm trees naturally occurring in the area, 40 babassu palm trees were selected for experimental data collection. Phenological and production evaluations of babassu were conducted from December 2017 to February 2019, which corresponds to two production seasons. Total plant height and circumference at breast height $(\mathrm{CBH})$ were measured using laser equipment (Bosch GLM40) and measuring tape, respectively. The height of the palms was defined as the distance between the soil level and the tree canopy.

All ripe bunches were dropped down with a pruning pole adapted with a small sickle. The bunches were considered ripe when the fruits started to fall spontaneously. The number of fruits was counted, and the total fruit mass was measured for each bunch. The reproductive phenological observations were performed monthly from January to December 2018. The presence and number of functionally male/female inflorescences (classified according to Anderson, Overal, \& Henderson, 1988) and unripe/ripe bunches were registered.

A group of traditional women babassu breakers (quebradeiras de coco babaçu) that live near the property was contacted for signing a partnership to evaluate all the management process, from collecting the fruits to processing all the fruit parts for income generation from NWFP of babassu (Figure 1). Two months of work of the group of breakers was registered to evaluate the performance of workers, the efficiency of activities and potential income generation by all the NWFP. The main variables evaluated were: 1) yield of seed and endocarp; 2) production and commercialization of babassu mesocarp flour; 3) production and commercialization of cakes and cookies made out of babassu mesocarp flour; 4) production and commercialization of babassu oil; and 5) production and commercialization of babassu endocarp charcoal.

In order to evaluate yield of seed and endocarp, a sample of 40 bags of $20 \mathrm{~kg}$ of fruit were dried at room temperature in a barn and broken by traditional method (manually, using an ax and a club). The yield of babassu mesocarp ( $15 \%$ of fruit mass), seeds ( $6 \%$ of fruit mass), oil (50\% of seed mass) and charcoal (30\% of endocarp mass) were estimated based on Frazão (1999), which measured these features in more than 3000 fruits from different environments.

Although 40 trees were evaluated in the 6-hectare area of ICLF production system, the potential income generation from babassu products was calculated based on the estimated production of 1.0 hectare, which means 35 palm trees per hectare (212 trees in 6 hectares). The regular local prices for babassu NWFP (flour, cookie, cake, oil and charcoal), as practiced by the group of women breakers in local market, were used for the estimations. The only exception was the babassu seeds which were used $\mathrm{R} \$ 3.04$ per $\mathrm{kg}$, in 2018 , as practiced by the National Food Supply Company (CONAB), according to the Minimum Price Policy for Sociobiodiversity-based Products (PGPMBio). The net income of the women breakers was estimated as the difference between all revenues and all costs, except for the cost of women labour itself. 
Ten commercialization scenarios were simulated with different possible combinations of NWFP, which were calculated considering all possible combinations of intermediate and final products:

Scenario 1: Mesocarp, Seeds and Charcoal

Scenario 2: Mesocarp, Oil and Charcoal

Scenario 3: Biscuit, Seeds and Charcoal

Scenario 4: Biscuit, Oil and Charcoal

Scenario 5: Cake, Seeds and Charcoal

Scenario 6: Cake, Oil and Charcoal

Scenario 7: Biscuit/cake (1/2 each), Seeds and Charcoal

Scenario 8: Biscuit/cake (1/2 each), Oil and Charcoal

Scenario 9: Mesocarp/cookie/cake ( $1 / 3$ each), Seeds and Charcoal

Scenario 10: Mesocarp/cookie/cake ( $1 / 3$ each), Oil and Charcoal

\section{Results}

Considering que whole experimental area, the mean height of all 40 babassu palm trees was $9.17 \mathrm{~m}( \pm 1.42 \mathrm{~m})$ and $\mathrm{CBH}$ was $106.48 \mathrm{~cm}( \pm 12.58 \mathrm{~cm})$. The palm trees presented regular fruit production during the two production seasons evaluated (2017-2018 and 2018-2019). As the most significant reproductive phenological results of the study, the opening of the first female functional inflorescence was observed in December, and the pollinated bunches developed from April through October (7 months), meanwhile the first ripe bunches were noticed in between September and October (Figure 2).

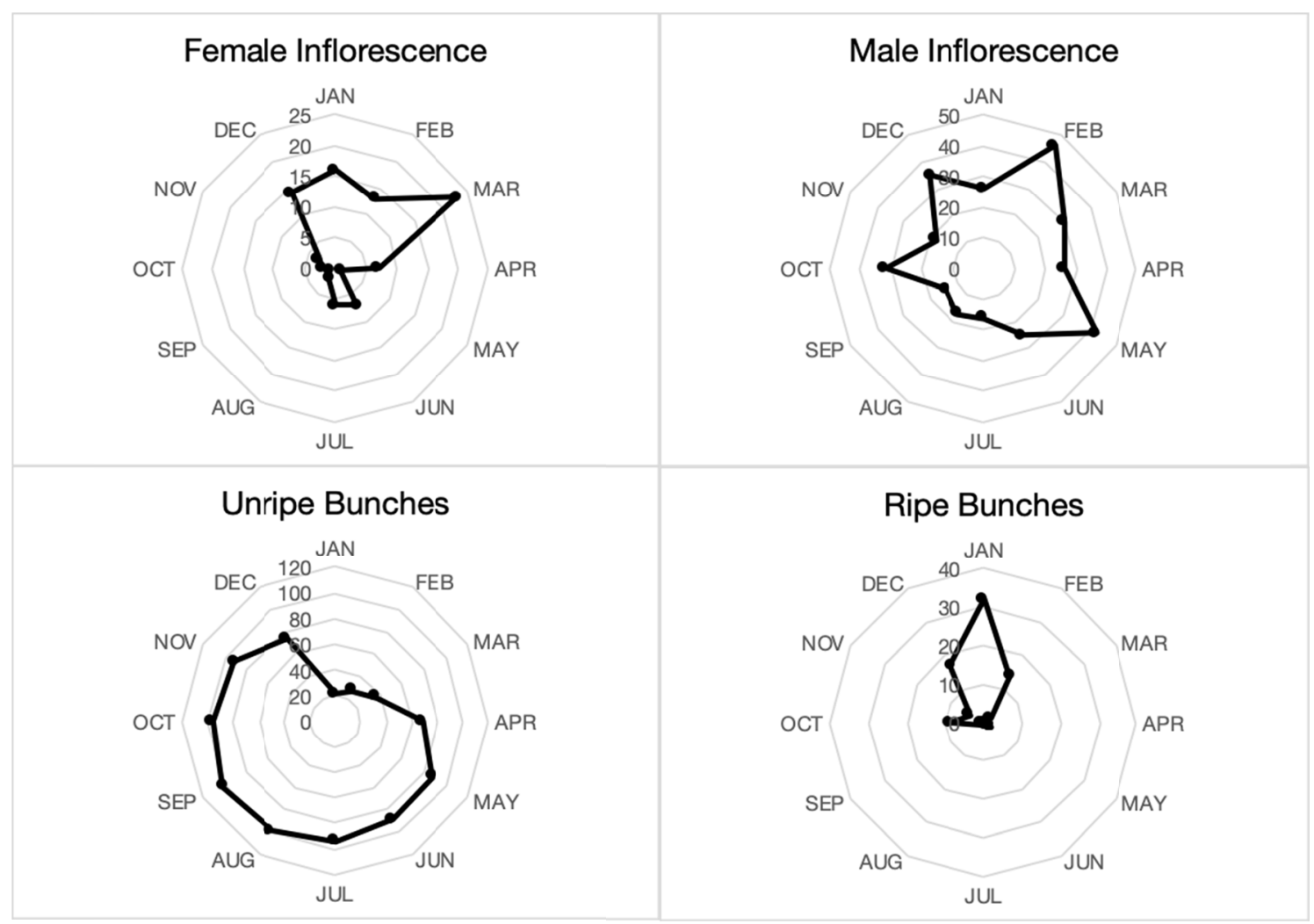

Figure 2. Reproductive phenology of 40 babassu palm trees (Atallea speciosa Mart. Ex Spreng) in an Integrated Crop-Livestock-Forestry system (12-month season of evaluation: January - December 2018).

The first fruit sample (December 2018) showed a high quantity of bunches collected due to the accumulation of previous months' riped bunches. March to September was the period with the lowest production (inter-season). 
During the traditional picking season (October to February) the mean production was 16 bunches per month, reaching its highest point in January (32 bunches, Figure 3). In two seasons, 169 bunches were produced which is equivalent to an average of 2.11 bunches per palm per season. The largest number of bunches produced by one single palm was 3.0 bunches in the first year and 5.0 bunches in the second year, representing more than $240 \mathrm{~kg}$ of fruits in the two seasons and a mean of 4.0 bunches per tree per season. The mean tree production was $67.4 \mathrm{~kg}$ of fruit per palm per season.

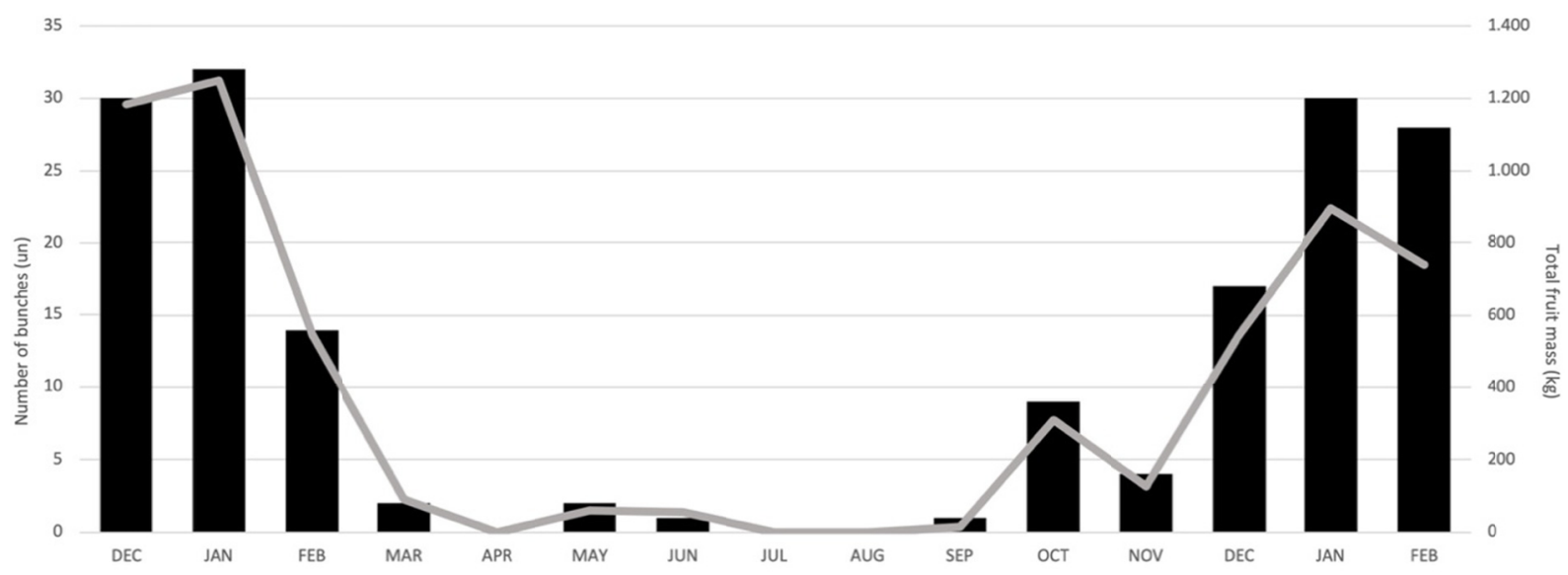

Figure 3. Quantity of bunches and fruit mass of 40 babassu palm trees (Atallea speciosa Mart. Ex Spreng); Bars: Number of bunches; Line: Total fruit mass $(\mathrm{kg})$. Numbers represent the average of two seasons of data collected in a production area of Integrated Crop-Livestock-Forestry system

The fruit mass per bunch $(\mathrm{n}=169)$ ranged from $5.32 \mathrm{~kg}$ to $62.98 \mathrm{~kg}$, and the average was $31.54 \pm 12.9 \mathrm{~kg}$. The most productive month was January with $1,249.73 \mathrm{~kg}$ of fruits collected. The total production of the 40 evaluated palm trees was $2,719.50 \mathrm{~kg}$ in the $2017-2018$ season and $2,591.05 \mathrm{~kg}$ in the $2018-2019$ season. The estimated production per hectare (35 palms trees) was $2,402.23 \mathrm{~kg}$ for the first season and 2,288.76 $\mathrm{kg}$ for the second. The mean was $2,345.49 \mathrm{~kg}$ of fruits per hectare per season (Table 1).

Table 1. Production of 40 babassu palm trees (Atallea speciosa Mart. Ex Spreng) in a production area of Integrated Crop-Livestock-Forestry system during two production seasons

\begin{tabular}{|c|c|c|c|c|c|c|c|c|}
\hline \multirow{3}{*}{ Season } & \multicolumn{4}{|c|}{ Quantity (un) } & \multicolumn{4}{|c|}{ Fruit Mass (kg) } \\
\hline & \multicolumn{2}{|c|}{ Bunch } & \multicolumn{2}{|c|}{ Fruit } & \multicolumn{2}{|c|}{ Sample $(n=40)$} & \multicolumn{2}{|c|}{ Per hectare $(n=35)$} \\
\hline & Total & Per tree & Total & Per tree & Total & Per tree & Total & Per tree \\
\hline 2017-2018 & 81 & 2.02 & 19524 & 488.1 & 2719.50 & 67.99 & 2402.23 & 60.06 \\
\hline 2018-2019 & 88 & 2.20 & 18487 & 462.2 & 2591.05 & 64,78 & 2288.76 & 57,22 \\
\hline Average & 84.5 & 2.11 & 19005.5 & 475.1 & 2655.27 & 66,38 & 2345.49 & 58,64 \\
\hline
\end{tabular}

The potential income of babassu NWFP was estimated based on the average production per hectare per season $(2,345.49 \mathrm{~kg})$ of the ICLF system (considering 35 palm trees per hectare) (Tables 2 and 3 ). The maximum potential income was found for scenario 6 , which provides an income of $\mathrm{R} \$ 36,628.54 \mathrm{ha}^{-1} \mathrm{year}^{-1}$ by selling three final products (cake, oil and charcoal). The lowest potential income was found for Scenario 1: $\mathrm{R} \$ 8,206.96 \mathrm{ha}^{-1}$ year $^{-1}$, by selling mesocarp, seeds and charcoal (two intermediate products). The Scenario 10, which features five different products (the largest diversity of products) for commercialization, resulted in a total income of $\mathrm{R} \$ 21,617.40 \mathrm{ha}^{-1}$ year $^{-1}$. 
Table 2. Estimates of potential income per product of babassu (Atallea speciosa Mart. Ex Spreng) from extractive activities in an Integrated Crop-Livestock-Forestry system

\begin{tabular}{|c|c|c|c|c|c|c|c|c|c|c|c|}
\hline \multicolumn{6}{|c|}{ Raw Processing—per season $\left(\mathrm{ha}^{-1}\right)^{\mathrm{a}}$} & \multicolumn{6}{|c|}{ Adding Value - per season $\left(\mathrm{ha}^{-1}\right)^{\mathrm{a}}$} \\
\hline $\begin{array}{l}\text { Babassu } \\
\text { Fruit Part }\end{array}$ & Product & $\begin{array}{l}\% \text { of } \\
\text { fruit } \\
\text { mass }\end{array}$ & $\begin{array}{l}\text { Total } \\
\text { production } \\
(\mathbf{k g})\end{array}$ & $\begin{array}{l}\text { Price } \\
\text { (R\$) }\end{array}$ & $\begin{array}{l}\text { Net } \\
\text { income } \\
(\mathrm{R} \$)\end{array}$ & $\begin{array}{l}\text { Commercial } \\
\text { unit }^{c}\end{array}$ & $\begin{array}{l}\text { Yield } \\
\text { per kg } \\
\text { of raw } \\
\text { material }\end{array}$ & Quantity $^{\mathrm{c}}$ & $\begin{array}{l}\text { Price } \\
\text { (R\$) }\end{array}$ & $\begin{array}{l}\text { Net } \\
\text { income } \\
\text { (R\$) }\end{array}$ & $\begin{array}{l}\text { Total Net } \\
\text { income } \\
(\mathrm{R} \$)\end{array}$ \\
\hline \multirow{3}{*}{ Mesocarp } & Flour & $15 \%$ & 351.82 & 20.00 & $7,036.40$ & - & - & - & - & - & - \\
\hline & Cookie & - & - & - & - & Packet & 50 & 17,591 & 2.00 & 1.00 & $17,591.00$ \\
\hline & Cake & - & - & - & - & Piece & 180 & 63,328 & 1.00 & 0.55 & $34,830.40$ \\
\hline \multirow{2}{*}{ Seed } & Seed & $6 \%$ & 140.73 & 3.04 & 427.82 & - & - & - & - & - & - \\
\hline & Seed Oil & - & - & - & - & Liter & 0.5 & 70.36 & 15.00 & 15.00 & $1,055.40$ \\
\hline \multirow{2}{*}{ Endocarp } & Shell & $76 \%$ & $1,782.57$ & - & - & - & - & - & - & - & - \\
\hline & Charcoal & - & - & - & - & $\mathrm{kg}$ & 0.33 & 594.19 & 1.25 & 1.25 & 742.74 \\
\hline
\end{tabular}

Note. (a) season = period of 12 months of babassu production and fruit processing (August-June); (b) estimated based on Frazão (1999); (c) units used by babassu breakers to sell the products in local markets.

Table 3. Simulated scenarios of commercialization for products of babassu (Atallea speciosa Mart. Ex Spreng) extractive activities in an Integrated Crop-Livestock-Forestry system (per hectare)

\begin{tabular}{|c|c|c|c|c|c|c|c|}
\hline \multicolumn{8}{|c|}{ Simulated commercialization scenarios (per season) } \\
\hline & Flour & Cookie & Cake & Seed & Seed Oil & Charcoal & Potential Net Income \\
\hline Scenario 1 & $\mathrm{X}$ & & & $\mathrm{X}$ & & $\mathrm{X}$ & $\mathrm{R} \$ 8,206.96$ \\
\hline Scenario 2 & $\mathrm{X}$ & & & & $\mathrm{X}$ & $\mathrm{X}$ & $\mathrm{R} \$ 8,834.54$ \\
\hline Scenario 3 & & $\mathrm{X}$ & & $\mathrm{X}$ & & $\mathrm{X}$ & $\mathrm{R} \$ 18,761.56$ \\
\hline Scenario 4 & & $\mathrm{X}$ & & & $\mathrm{X}$ & $\mathrm{X}$ & $\mathrm{R} \$ 19,389.14$ \\
\hline Scenario 5 & & & $\mathrm{X}$ & $\mathrm{X}$ & & $\mathrm{X}$ & $\mathrm{R} \$ 36,000.96$ \\
\hline Scenario 6 & & & $\mathrm{X}$ & & $\mathrm{X}$ & $\mathrm{X}$ & $\mathrm{R} \$ 36,628.54$ \\
\hline Scenario $7^{a}$ & & $\mathrm{X}$ & $\mathrm{X}$ & $\mathrm{X}$ & & $\mathrm{X}$ & $\mathrm{R} \$ 27,381.26$ \\
\hline Scenario $8^{\mathrm{a}}$ & & $\mathrm{X}$ & $\mathrm{X}$ & & $\mathrm{X}$ & $\mathrm{X}$ & $\mathrm{R} \$ 28,008.84$ \\
\hline Scenario $9^{b}$ & $\mathrm{X}$ & $\mathrm{X}$ & $\mathrm{X}$ & $\mathrm{X}$ & & $\mathrm{X}$ & $\mathrm{R} \$ 20,989.82$ \\
\hline Scenario $10^{b}$ & $\mathrm{X}$ & $\mathrm{X}$ & $\mathrm{X}$ & & $\mathrm{X}$ & $\mathrm{X}$ & $\mathrm{R} \$ 21,617.40$ \\
\hline
\end{tabular}

Note. (a) use of flour: 1/2 for cookie and 1/2 for cake; (b) use of flour: 1/3 for commercialization, 1/3 for cookie, and $1 / 3$ for cake.

\section{Discussion}

The babassu fruit production in the studied ICLF system $\left(2,345 \mathrm{~kg} \mathrm{ha}^{-1}\right)$ is the most accurate data for babassu production available. This study is the first in which the productivity of 40 individuals was evaluated monthly throughout two production seasons. Most past studies extrapolated data from few samples $\left(935\right.$ to $5,534 \mathrm{~kg} \mathrm{ha}^{-1}$, Ministério da Indústria e Comércio, 1982) or presented poorly detailed methodologies $\left(4,428\right.$ to $8,857 \mathrm{~kg} \mathrm{ha}^{-1}$, Lemos \& Souza, 2018).

Regarding seasonality, the palm phenology data clearly demonstrated that the activity of fruit gathering by extractive workers could be concentrated from October to February, which represents $90 \%$ of production. Therefore, due to its perishability, the starchy mesocarp extraction and flour production would be suitable for being conducted during those months, and seed extraction and charcoal production could be concentrated in the inter-season months (March through September). Finally, this strategy might also allow to commercialize seed and seed oil during the inter-season, ensuring more attractive prices. Therefore, the planning and strategy of extractive activity throughout the year is clearly very important for higher yield in the region and better prices in the local market (Pettenella \& Maso, 2009).

Although the potential of NWFP contribution to income and improvement in livelihoods should not be exaggerated (Ros-Tonen, 2000), the innovative ICLF system with babassu palm as a forestry component show a high potential for social benefits, since it could generate substantial income for surrounding communities 
exploiting babassu NWFP, which corroborates our main hypothesis. According to the evaluated scenarios, processing and using various babassu products might allow, extractive communities to generate a total estimated income ranging from $\mathrm{R} \$ 8,000.00$ (Scenario 1) to $\mathrm{R} \$ 36,000.00$ (Scenario 6) per year and hectare. Regarding the rural context of Maranhão state, this potential income (monthly from $\mathrm{R} \$ 667.00$ to $\mathrm{R} \$ 3,000.00$ ) could be considered relevant for the rural population. The average nominal monthly income in the whole state territory was R \$ 605.00 per residence (Instituto Brasileiro de Geografia e Estatística [IBGE], 2018) and that 54\% of the residences of the municipality of Pindaré-Mirim had monthly per capita income lower than $50 \%$ of minimum national wage (R\$ 499.00; IBGE, 2010). However, the analyzed scenarios must be deepen evaluated.

As expected, scenarios that use a portfolio with products that demand more labour and, consequently, with a higher added value, showed higher potential for net income (Scenarios 5 to 10). However, the most profitable scenarios used a portfolio with a high concentration of sales in one or two mesocarp products (Scenarios 5 to 8 ). Porro (2019) showed that the mesocarp is the least used part of the fruit. It demonstrates that there is no tradition to use this babassu NWFP and there is a lack of technical knowledge that can be a constraint to mesocarp using. Furthermore, as stressed by Marshall, Newton, and Schreckenberg (2003), marketing and sales are commonly the most constraining processes in NWFP exploitation. It will probably be true to high concentrated Scenarios 5 to 8 . It is unlikely that a worker would be able to sell large amounts of one product in local market by a profitable price. For that reason, the proposed Scenarios 5 to 8 are unlikely to succeed. Finally, scenarios 9 or 10 presented high diversification of products in the portfolio and, consequently, decreased the risk of the extractive business. Therefore, planning for diversification is an important factor to mitigate risks and increase the likelihood of success (Ball \& Brancalion, 2016; Pettenella \& Maso, 2009) and the decision between selling one specific portfolio must be based on the production capacity and the perception of local consumer market (Marshall et al., 2003).

It must be moreover highlighted that the babassu extractive activity faces a lot of issues. All the processes presented in Figure 1, that is, picking, transportation and processing, are highly laborious practices: Manual harvesting must be done constantly during the harvest season in order to enable extraction of the perishable mesocarp as soon as possible. Freshly fallen fruits cannot remain on the ground for more than two days and the ripe fruits must be collected. Transportation can be done manually, by animals or even by motorcycles, depending on the conditions of access to the productive areas and the roads that lead to the villages, often precarious. It is necessary knowledge of processing techniques (traditional or not), equipment and infrastructure (not always available) to facilitate the use of all fruit parts (mesocarp, endocarp, and seeds). There is a lack of equipment and machinery suitable for this type of work, and those that exist are not accessible to babassu extractivists due to their high cost.

Therefore, not all communities would be readily able to make the full potential income out of babassu fruits in the ICLF system or the native areas. Then, in order to take full advantage of the potential that babassu NWFP can provide in the ICLF system, it is necessary that the basic needs of communities are met by public policies (Ros-Tonen, 2000), and that an institutional framework allows access to technical and financial support (Meinhold \& Darr, 2019).

The babassu extractive and intensive processing activities lead to an increase in workload in the countryside, especially for women, which provokes some positive changes, such as cooperation and better social interaction (Porro, 2005). However, many aspects of the intensive expenditure of labour on this activity conflicts with some relevant socio-cultural practices in rural communities. The time demand for domestic tasks, for instance, is still concentrated on women, which can be incompatible with the intensive labour-demanding extractive activity. Thus, cooperativism may be an alternative, because it allows to gain in scale, advance in specialization and improve in productivity and commercialization (Meinhold \& Darr, 2019), as well as for accessing some public policies, such as PGPMBio (Porro, 2019). The diversification of activities and inclusion of rural population, especially young people, would also increase the possibility of preservation of extractive labour as an income source in the countryside.

The conflict produced by the coexistence of babassu extractivism and livestock activity is widely discussed (Porro, 2005; R. Porro \& N. S. M. Porro, 2015). However, the search for appropriate management techniques for the coexistence of these two activities have only recently been addressed (Rodrigues et al., 2015, 2016; Araújo et al., 2018). Focusing on babassu production and income generation by extractive families in an area of ICLF system, we concluded that the activity can be profitable for workers in that community and that more diverse portfolio products are more likely to succeed. 
Moreover, the babassu extraction can be beneficial for ranchers, since the picking of fruits prevents the excessive sprouting of newer babassu plants (pindovas), reducing the costs for their control. Therefore, the results found here may contribute for demonstrating an ICLF production system based on agronomic and zootechnical ongoing studies which search for ideal practices for the coexistence of extractivism of babassu and livestock activities. We suggest that the issues to be addressed on new studies must be the most suitable density of palms in the ICLF system and the calculation of labour force in extraction and processing. The later will enable the estimation of supportability of extractivism in the innovative ICLF system.

\section{Conclusion}

We conclude that the potential income generated by NWFP extractivism at ICLF adapted system is economically suitable for traditional communities of women babassu breakers in Brazil, since it was higher than average income registered in official data for the region. The commercialization scenarios which presented high diversification of products in the portfolio are more likely to success. Then the production capacity and the perception of local consumer market must be constantly evaluated by extractivists.

\section{Acknowledgements}

The authors thank to Banco da Amazônia for financing the research, to Abimael de Matos Barbosa for field work help, to Luciano Cavalcante Muniz for providing the land and farm structure for study, to Luís Carlos Nogueira for revision and text improvements, to women babassu brakers from Morada Nova (Pindaré-Mirim municipality) for accepting and participating in the research and to FAPEMA for support Diego Santos scholar fellowship.

\section{References}

Alvares, C. A., Stape, J. L., Sentelhas, P. C., Gonçalves, J. L. M., \& Sparrovek, G. (2014). Köppen’s climate classification map for Brazil. Meteorologische Zeitschrift, 22(6), 711-728. https://doi.org/10.1127/09412948/2013/0507

Alves, B. J. R., Madari, B. E., \& Boddey, R. M. (2017). Integrated crop-livestock-forestry systems: Prospects for a sustainable agricultural intensification. Nutrient Cycling in Agroecosystems, 108, 1-4. https://doi.org/ $10.1007 / \mathrm{s} 10705-017-9851-0$

Anderson, A. B., Overal, W. L., \& Henderson, A. (1988). Pollination Ecology of a Forest-Dominant Palm (Orbignya phalerata Mart.) in Northern Brazil. Biotropica, 20(3), 192-205. http://doi.org/10.2307/2388234

Araújo, R. A., Rodrigues, R. C., Costa, C. S., Lana, R. P., Santos, F. N. S., Temístocles, A. J., \& Rodrigues, M. M. (2016). Forage intake and performance of cattle in silvo-pastoral systems and monoculture of Marandu in Pre-Amazon region. African Journal of Agricultural Research, 11(20), 1849-1857. https://doi.org/10.5897/ ajar2016.10795

Araújo, R. A., Rodrigues, R. C., Costa, C. S., Santos, F. N. S., Andrade, A. C., Silva, I. R., ... Junior, J. A. A. C. (2018). Nutrient intake and economic analysis of young bulls reared in silvopastoral systems with babassu palm trees in the Pre-Amazon region. Revista Brasileira de Saúde e Produção Animal, 19(3), 241-255. https://doi.org/10.1590/s1519-99402018000300002

Balbino, L. C., Barcellos, A. O., \& Stone, L. F. (2011). Reference document crop-livestock-forestry integration. Brasília, DF: Embrapa.

Ball, A., \& Brancalion, P. (2016). Governance challenges for commercial exploitation of a non-timber forest product by marginalized rural communities. Environmental Conservation, 43(3), 208-220. https://doi.org/ $10.1017 / \mathrm{S} 0376892916000072$

Calama, R., Tomé, M., Sánchez-González, M., Miina, J., Spanos, K., \& Palahi, M. (2010). Modelling non-wood forest products in Europe: A review. Forest Systems, 19(SI), 69-85. https://doi.org/10.5424/fs\%2F20 1019S-9324

Costa, M. P., Schoeneboom, J. C., Oliveira, S. A., Viñas, R. S., \& Medeiros, G. A. (2018). A socio-eco-efficiency analysis of integrated and non-integrated crop-livestock-forestry systems in the Brazilian Cerrado based on LCA. Journal Cleaner Production, 171, 1460-1471. https://doi.org/10.1016/j.jclepro.2017.10.063

Eichhorn, M. P., Paris, P., Herzog, F., Incoll, L. D., Liagre, F., Mantzanas, K., ... Dupraz, C. (2006). Silvoarable systems in Europe-Past, present and future prospects. Agroforestry Systems, 67, 29-50. https://doi.org/ 10.1007/s10457-005-1111-7 
Elmqvist, B., Olsson, L., Elamin, E. M., \& Warren, A. (2005). A traditional agroforestry system under threat: An analysis of the gum arabic market and cultivation in the Sudan. Agroforestry Systems, 64, 211-218. https://doi.org/10.1007/s10457-004-2371-3

Frazão, J. M. F. (1999). Sistemas de modelos agroecológicos de intervenção em áreas de babaçuais para o planejamento de uma agricultura sustentável para o município de São Domingos do Maranhão (Unpublished Master's Thesis, State University of Maranhão, São Luís, Brazil).

Henderson, F. M. (2006). Morphology and anatomy of palm seedlings. Botanical Review, 72(4), 273-329. https://doi.org/10.1663/0006-8101(2006)72[273:MAAOPS]2.0.CO;2

IBGE (Instituto Brasileiro de Geografia e Estatística). (2010). Censo Demográfico 2010. Retrieved from https://cidades.ibge.gov.br/brasil/ma/panorama

IBGE (Instituto Brasileiro de Geografia e Estatística). (2018). Pesquisa Nacional por Amostra de Domicílios Contínua-2018. Retrieved from https://www.ibge.gov.br/estatisticas/sociais/populacao/17270-pnad-continua html? $=\& \mathrm{t}=\mathrm{o}-\mathrm{que}-\mathrm{e}$

Jackson, G. (1974). Cryptogeal germination and other seedling adaptions to the burning of vegetation in savanna regions: the origin of the pyrophytic habit. New Phytologist, 73, 771-780. https://doi.org/10.1111/ j.1469-8137.1974.tb01305.x

Köppen, W. (1948). Climatologia: Con un estudio de los climas de la tierra. Fondo de Cultura Econômica, México.

Lemos, J. J. S., \& Souza, R. C. (2018). Sistemas agroextrativistas como alternativa de preservação da palmeira de babaçu no Maranhão. Revista de Política Agrícola, 27(1), 82-95.

Lima, I. L. P., Scariot, A., \& Giroldo, A. B. (2017). Impacts of the implementation of silvopastoral systems on biodiversity of native plants in a traditional community in the Brazilian Savanna. Agroforestry Systems, 91, 1069-1078. https://doi.org/10.1007/s10457-016-9981-4

Magalhães, C. A. S., Pedreira, B. C., Tonini, H., \& Farias Neto, A. L. (2019). Crop, livestock and forestry performance assessment under different production systems in the north of Mato Grosso, Brazil. Agroforestry Systems, 93, 2085-2096. https://doi.org/10.1007/s10457-018-0311-x

Marshall, E., Newton, A., \& Schreckenberg, K. (2003). Commercialisation of non-timber forest products: First steps in analysing the factors influencing success. International Forestry Review, 5(2), 128-137. https://doi.org/10.1505/IFOR.5.2.128.17410

May, P. H., Anderson, A. B., Frazão, J. M. F., \& Balick, M. J. (1985). Babassu palm in the agroforestry systems in Brazil's Mid-North region. Agroforestry Systems, 3, 275-295. https://doi.org/10.1007/BF00046960

May, P. H. (1990). Palmeiras em Chamas: transformação agrária e justiça social na zona do babaçu. São Luís, MA: EMAPA.

Meinhold, K., \& Darr, D. (2019). The Processing of Non-Timber Forest Products through Small and Medium Enterprises-A Review of Enabling and Constraining Factors. Forests, 10, 1026. https://doi.org/10.3390/ f10111026

Ministério da Indústria e Comércio/Secretária de Tecnologia Industrial. (1982). Mapeamento e Levantamento do potencial das ocorrências dos babaçuais no Maranhão, Piauí, Mato Grosso e Goiás. Brasília, DF: $\mathrm{MIC} / \mathrm{STI}$.

Pettenella, D., \& Maso, D. (2009). The Role of Networks in Non-Wood Forest Products and Services Marketing in Europe. In M. Palahi, Y. Birot, F. Bravo, \& E. Gorriz (Eds.), Modelling, valuing and managing mediterranean forest ecosystems for non-timber goods and services. European Forest Institute, Finland.

Peters, C. M. (1992). The ecology and economics of oligarchic Amazonian forests. Advances in Economic Botany (Vol. 9). New York, NY: The New York Botanical Garden.

Pinheiro, C. U. B. (1986). Germinação de Sementes de Palmeiras: Revisão Bibliográfrica. Teresina, PI: Embrapa.

Pinheiro, F. M., \& Nair, P. K. R. (2018). Silvopasture in the Caatinga biome of Brazil: A review of its ecology, management, and development opportunities. Forest Systems, 27(1), eR01S. https://doi.org/10.5424/ fs/2018271-12267 
Porro, R. (2005). Palms, Pastures, and Swidden Fields: The Grounded Political Ecology of "Agro-Extractive/Shifting-cultivator Peasants" in Maranhão, Brazil. Human Ecology, 33(1), 17-55. https://doi.org/10.1007/s10745-005-1654-2

Porro, R. (2019). A economia invisível do babaçu e sua importância para meios de vida em comunidades agroextrativistas. Boletim do Museu Paraense Emílio Goeldi. Ciências Humanas, 14(1), 169-188. https://doi.org/10.1590/1981.81222019000100011

Porro, R., \& Porro, N. S. M. (2015). Identidade social, conhecimento local e manejo adaptativo de comunidade tradicionais em babaçuais no Maranhão. Ambiente \& Sociedade, 18(1), 1-18. https://doi.org/10.1590/ 1809-4422ASOC507V1812015en

Reis, V. R., Deon, D. S., Muniz, L. C., Silva, M. B., Rego, C. A. R. M., Garcia, U. S., ... Costa, J. B. (2018). Carbon Stocks and Soil Organic Matter Quality Under Different of Land Uses in the Maranhense Amazon. Journal of Agricultural Science, 10(5), 329-337. https://doi.org/10.5539/jas.v10n5p329

Rodrigues, R. C., Araújo, R. A., Costa, C. S., Lima, A. J. T., Santos, F. N. S., Araújo, J. S., \& Junior, J. A. A. C. (2015). Soil microbial biomass in an agroforestry system of Northeast Brazil. Tropical Grasslands-Forrajes Tropicales, 3(1), 41-48. https://doi.org/10.17138/TGFT(3)41-48

Rodrigues, R. C., Lima, A. J. T., Araújo, R. A., Jesus, A. P. R., Costa, C. S., Santos, F. N. S., ... Azevêdo, D. M. M. R. (2016). Agronomic, morphogenic and structural characteristics of Marandu grass in silvopastoral systems composed of babassu palm and grass monoculture. Semina: Ciencias Agrarias, 37(4), 2331-2341. https://doi.org/10.5433/1679-0359.2016v37n4Supl1p2331

Ros-Tonen, M. (2000). The role of non-timber forest products in sustainable tropical forest management. Holz als Roh-und Werkstoff, 58, 196-201. https://doi.org/10.1007/s001070050413

Skorupa, L. A., \& Manzatto, C. V. (2019). Sistemas de integração lavoura-pecuária-floresta no Brasil: Estratégias regionais de transferência detecnologia, avaliação da adoção e de impactos. Brasília, DF: Embrapa.

Sonwa, D. J., Okafor, J. C., Mpungi Buyungu, P., Weise, S. F., Tchatat, M., Adesina, A. A., ... Endamana, D. (2002). Dacryodes edulis, a neglected non-timber forest species for the agroforestry systems of west and central Africa. Forest Trees and Livelihoods, 12, 41-55. https://doi.org/10.1080/14728028.2002.9752409

Souza, J. T. R., Moraes, F. H. R., \& Gehring, C. (2016). Root biomass in a shifting cultivation system in the eastern periphery of Amazonia, and contribution of the babassu palm. Agroforestry Systems, 90, 351-360. https://doi.org/10.1007/s10457-015-9859-x

SEPLAN (Secretaria de Estado do Planejamento e Orçamento). (2013). Atlas do Maranhão, Núcleo Geoambiental—UEMA. São Luís, MA: UEMA.

Valipour, A., Plieninger, T., Shakeri, Z., Ghazanfari, H., Namiranian, M., \& Lexer, M. J. (2014). Traditional silvopastoral management and its effects on forest stand structure in northern Zagros, Iran. Forest Ecology and Management, 327, 221-230. https://doi.org/10.1016/j.foreco.2014.05.004

\section{Copyrights}

Copyright for this article is retained by the author(s), with first publication rights granted to the journal.

This is an open-access article distributed under the terms and conditions of the Creative Commons Attribution license (http://creativecommons.org/licenses/by/4.0/). 